\title{
Sustainable Use of Natural Zeolites in Aquaculture: A Short Review
}

\author{
Mohamed M Abdel-Rahim* \\ Fish Rearing Lab, National Institute of Oceanography and Fisheries (NIOF), Egypt
}

Submission:March 05, 2017; Published: May 02, 2017

*Corresponding author: :Mohamed M Abdel Rahim, Egypt, Tel: +201006929599; Email:mohamed_m_ar@yahoo.com

Abstract

Aquaculture contributes with $44.14 \%$ of total global fish production in 2014 compared with $4 \%$ in 1970 [1], while in Egypt, it contributes with $76 \%$ of the total Egyptian fish production in 2015 compared with 15\% in 1995 [2]. As a result of the negative impacts of traditional aquaculture systems, sustainable farming systems started to attract the attention of decision makers in many countries around the world. Zeolites is considered, as one of the most promising solutions which raised strongly a few years ago to achieve sustainability in aquaculture sector. Herein lies the importance of zeolite on aquaculture.

Keywords: Natural zeolites; Sustainable aquaculture; Water quality; Ammonia; Heavy metals; filters

\section{What is Zeolites?}

Zeolite can be defined as a group of crystalline microporous, aluminosilicate minerals with chemically neutral basic formed in a honeycomb-like structure. It is originated from volcanic rocks. Zeolite is characterized by structural stability at extreme temperatures $750^{\circ} \mathrm{C}$. Recently, Zeolites could be produced industrially on a large commercial scale with improved efficiency. There are more than 45 types of natural zeolites, and 150 types of synthetic zeolites. Clinoptilolite ( $\mathrm{Na}, \mathrm{K}, \mathrm{Ca}, \mathrm{Mg}$, $6\left(\mathrm{Al}_{6} \mathrm{Si}_{30} \mathrm{O}_{72}\right)$. $\sim 2 \mathrm{H}_{2} \mathrm{O}$ ) is one of the purest, effective, and cheapest types of zeolites.

\section{What is the Mechanism of Action of Zeolite?}

Table 1: Physical Properties of Pure Natural Zeolite.

\begin{tabular}{|c|c|}
\hline Specifications & Property \\
\hline White/gray/green & Color \\
\hline $24.9-40$ & Surface Area $-\mathrm{m}^{2} / \mathrm{gm}$ \\
\hline $800-1041$ & Bulk Density - $\mathrm{kg} / \mathrm{m}^{3}$ \\
\hline $1.6-2.0$ & Cation Exchange Capacity (CEC) \\
\hline $0.4-0.7$ & pore diameter, $\mathrm{nm}$ \\
\hline $11-\mathrm{Mar}$ & Stability, $\mathrm{pH}$ \\
\hline 0.65 & Particle size - mm \\
\hline 1.89 & specific gravity \\
\hline $5-\mathrm{Apr}$ & Hardness, mohs \\
\hline 1.6 & Uniformity coefficient $-\left(\mathrm{d}_{60} / \mathrm{d}_{10}\right)$ \\
\hline Less than 10 & Moisture - $\%$ \\
\hline
\end{tabular}

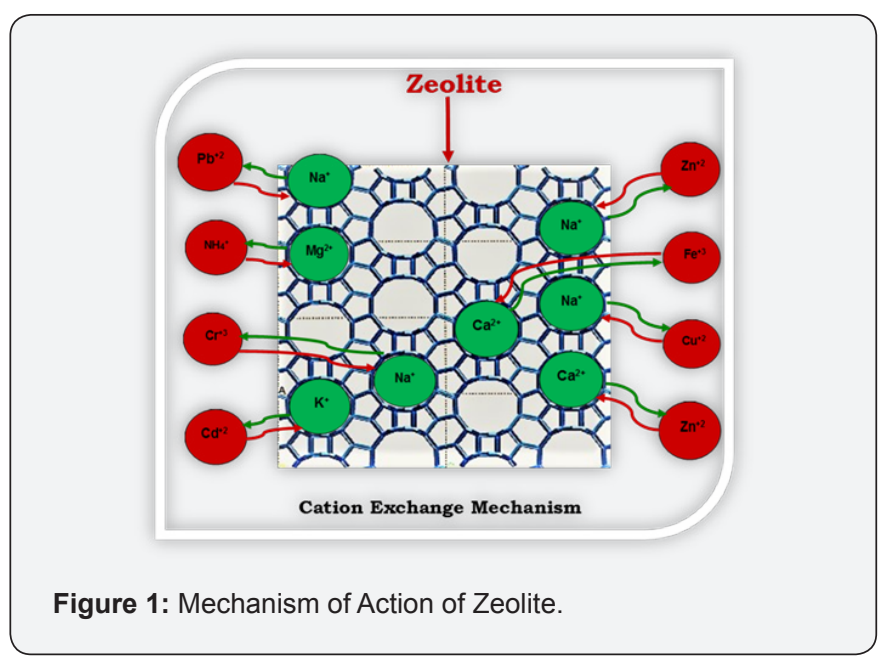

It depends on its structure. This structure forms a network of channels and cavities that allow easy penetration of micronsized molecules and filtering them according to size, polarity and shape, leading to adsorption and filtration of various substances that come into contact with zeolites. The unique structure of zeolites (Table 1) with high porosity allows efficient adsorption (charging) and rapid loss (re-generation) of wide range of charged elements such as ammonia, heavy metals, pesticides, smells, radioactive cations and many other toxins. One of the significant mechanisms involved in toxins uptake is known as Cation Exchange Capacity (CEC), which is defined as stoichiometric replacement of one equivalent of an ion in solid 
phase by equivalent of another ion in liquid phase [3]. CEC reaction takes place between exchangeable cations $\left(\mathrm{Na}^{+}, \mathrm{K}^{+}, \mathrm{Ca}^{2+}\right.$ and $\left.\mathrm{Mg}^{2+}\right)$ located in zeolite structure and cations $\left(\mathrm{NH}^{+4}, \mathrm{Cd}+2\right.$, $\mathrm{Cu}^{+2}, \mathrm{Hg}^{+2}, \mathrm{~Pb}^{+2}, \mathrm{Cs}^{+}, \mathrm{Mn}^{+}, \mathrm{Rb}^{+}, \mathrm{Li}^{+}, \mathrm{Ag}^{+}, \mathrm{Sr}^{+2}, \mathrm{Hg}^{+2}, \mathrm{Zn}^{+2}, \mathrm{Fe}^{+3}, \mathrm{Cr}^{+3}$, $\mathrm{Co}^{+3}$, etc.) in solution [4] (Figure 1). This ability puts zeolites on the top class of materials known as, Molecular Sieves. When zeolite is saturated with cations, it should be reactivated though washing in clean salt water and re-used many times before being $100 \%$ clogged. It was found that the loss of clinoptilolite capacity to be regenerated may occur after 10-11 regenerations [5,6].

\section{Importance of zeolites in sustainable aquaculture industry}

Zeolites have a tremendous value. They are widely being used in aquaculture industry in many countries in Southeast Asia and Latin America to improve water [7] and feed quality, to reduce the negative environmental impacts of aquaculture and to improve the quality of cultivated seafoods.

\section{Zeolites improve water quality}

Using zeolites to improve water quality is widely documented, especially in freshwater aquaculture, while the level of success in brackish and in marine aquaculture was significantly reduced $[8,9]$ by the high content of $\mathrm{Na}, \mathrm{Ca}, \mathrm{Mg}$, and other cations [7]. There are many factors affecting efficiency of zeolite, such as conductivity, $\mathrm{pH}$, temperature and initial concentration of cations of the treated water, concentration and particle size of zeolite, and exposure time. Zeolite could be used to reduce or eliminate the content of ammonia, nitrite, hydrogen sulfide, heavy metals, and organic materials in fish ponds, increase the content of oxygen, adjust $\mathrm{pH}$ and minimize odors emitted from fish excretion. Zeolites could be added to the rearing water to achieve the following aims:

\section{Ammonia removal}

Zeolites has the ability to reduce the content of ammonia in both fresh and marine waters with efficiency exceeded $83 \%$ when the initial content of ammonia was $\leq 1.0 \mathrm{ppm}[9,10]$. The greater the initial concentration of ammonia, the lesser NH3- removal efficiency. Ammonia removal efficiency in freshwater is better than marine water. In this regard, with initial concentration $3 p p m$, ammonia removal efficiency was $40 \%$ more in fresh water compared with marine water (30ppt). Decreasing zeolite particle size improves the CEC of ammonia. CEC was found to be 0.57 and $0.38 \mathrm{meq} \mathrm{NH}^{+} / \mathrm{g}$ zeolite for fine $(1.00-0.125 \mathrm{~mm})$ and coarse $(2.00-1.00 \mathrm{~mm})$ sizes of clinoptilolite, respectively [11]. Also, Malovanyy et al. [12] concluded that maximum adsorption capacity was $74.7 \mathrm{mg} \mathrm{NH} 4^{+} / \mathrm{g}$ zeolite with ammonia removal efficiency varied between 88-99.9\%. How to put up zeolite in fish rearing water, greatly affect its efficiency in ammonia removal. Öz et al. [13] detected that zeolite that was put inside a net bag reduced ammonia content in fish tanks $72 \%$, while zeolite that was put in aquarium directly reduced ammonia by
$33 \%$ compared with control. Although the removal efficiency of ammonia in saltwater are relatively less than in freshwater, but still the highest efficiency and lowest cost compared to other materials in the same class such as activated carbon [10].

\section{Heavy metals removal}

Heavy metals removal by natural zeolites has been considered in recent years. Gholikandi et al. [14] showed that the natural zeolite could remove different heavy metals from drinking water.Cadmium content $(6 \mathrm{ppm})$ in the rearing water of Mozambique tilapia could be reduced after 45 Days exposure time with removal efficiency $75 \%$ using zeolite at $4 \mathrm{gm} /$ litre [15]. Heavy metals removal efficiency from aqueous solutions using zeolite is affected by several factors, such as $\mathrm{pH}$, temperature, presence of other contaminants in the treated water, properties of heavy metal ions, pre treatment applied to zeolite, pore clogging, particle size, and zeolite purity [15]. Also, removal efficiency of zeolite for other heavy metals such as cadmium, chrome, copper, nickel, zinc, iron, and lead was 90, 90, 90, 75, 85,70 , and $95 \%$, respectively. The CEC of the natural zeolite for some heavy metals may amount to: $\left(\mathrm{Fe}^{2+} 1.0 \mathrm{meq} / \mathrm{g}-\mathrm{Zn}^{2+1} .1 \mathrm{meq} /\right.$ g-Ni ${ }^{2+} 1.0 \mathrm{meq} / \mathrm{g}-\mathrm{Cd}^{2+} 1.0 \mathrm{meq} / \mathrm{g}-\mathrm{Pb}^{2+} 1.2 \mathrm{meq} / \mathrm{g}-\mathrm{Cu}^{2+} 1.0 \mathrm{meq} / \mathrm{g}$ zeolite) [16]. So, zeolite is considered the best material to remove heavy metals from aqueous contaminated media with high efficiency and low cost.

\section{Decrease turbidity}

Zeolite has the ability to decrease the content of suspended organic matter and TDS [16] in fish ponds, which certainly affect water quality, fish health and growth performance. In a field experiment (unpublished data) carried out in Egypt, it was found that earthen ponds treated with zeolite resulted a decrease in total dissolved solids (TDS) from 635 to $400(\mathrm{mg} / \mathrm{l}), \mathrm{pH}$ from 8.65 to 8.4 , ammonia from 0.51 to $0.01 \mathrm{ppm}$ and better phytoplankton abundance comparing with non- treated zeolite ponds (Figure 2). Even with zeolite incorporated in fish feed, water turbidity is diminished. Turbidity of tank water from goldfish fed zeolite diets was effected by dietary treatment, whereby the $2 \%$ zeolite diet reduced significantly turbidity compared to the diet containing no zeolite [17].

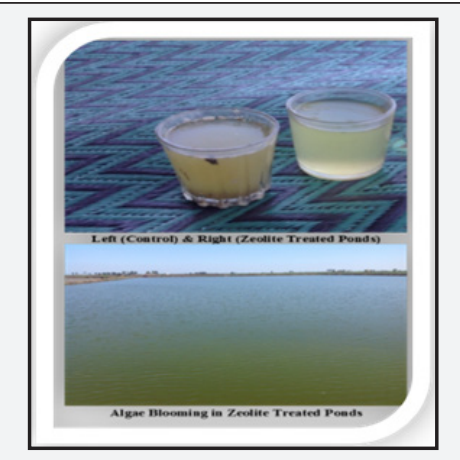

Figure 2: Comparison between turbidity content in earthen fish ponds treated and non-treated with zeolite. 


\section{Enhancement of diatom growth}

Nieves et al. [7] stated that an enhancement of diatom, Chaetoceros sp. growth was obtained in culture medium $\mathrm{f}$ enriched with natural and artificial zeolites compared with non-enriched medium. The previous authors did not find an explanation for this result, despite Chien [18] attributed the promotion of diatom growth to zeolite silicon leaching in seawater.

\section{Decrease hardness}

It is possible to purify and enhance the quality of the hard waters in fish farms using zeolite. Sodium ions exist in natural zeolite, can easily be loosed or replaced with other cations. Therefore, when hard water is passed through a bed of active granular zeolite, the sodium zeolite will be converted to calcium and magnesium zeolites. This means that water becomes free or less content of $\mathrm{Ca}^{2+}$ and $\mathrm{Mg}^{2+}$, (less hardness) [16,19]. For further confirmation, water hardness decreased significantly with values (328.4 to $42.4 \mathrm{mg} / \mathrm{L}$ ) together with the partial removal of $\mathrm{Ca}^{2+}$ and $\mathrm{Mg}^{2+}$ ions using natural zeolites [20].

\section{Zeolites Improve Feed Utilization Index}

Zeolites have been registered in the European Union as feed additives (binders, anti-caking agents and coagulants) based on the regulation No. 831/2003, edition 186.They have been recommended in artificial feeds to reduce toxic effects of aflatoxins [21] and as an antimicrobial agent [22]. Applying zeolites in fish feed will control mycotoxins, increase feed consumption, reduce the conversion coefficient of dietary protein, reduce feed conversion rate, improve growth rate, improve condition factor, reduce mortality, and increase production [23-27]. Feeding Nile tilapia, Oreochromis niloticus on artificial feed enhanced with $2 \%$ zeolite increased final weight, SGR and improved the economic efficiency in terms of the net returns to total costs with $31 \%$ increment [25]. The highest apparent digestibility coefficients of dietary dry matter and protein were achieved in common carp fed diets supplemented with $5 \%$ zeolite [28]. Contaminated feed ingredients can be partially controlled using zeolite. Inclusion of dietary zeolite with three levels of zeolite $(1,3,5 \%)$ reduces aflatoxin $B_{1}$ levels (11.48 and 4.8ppm) in contaminated bread wastes used as cattle feed after 14 days of storage. The lowest level of aflatoxin was found in feed treated with 5\% zeolite [29]. Ecologically, seabream fingerlings fed with diet contained $2 \%$ zeolite, excreted less total solid waste (TSW), total nitrogen waste (TNW), and solid nitrogen waste (SNW) per $\mathrm{g} / \mathrm{kg}$ produced fish compared with control [23]. Also, goldfish fed 2\% zeolitesupplemented diets had significantly less total ammonia, and less turbidity compared withcontrol [17]. For more confirmation about this point, Ergun et al. [30] found that rainbow trout fed diets containing $2.5 \%$ zeolite showed lower total ammonia production compared to control diet. This means that zeolite contributes to the reduction of theharmful environmental impacts of aquaculture activity (support sustainability).

\section{Zeolites Improve Fish Health \& Beauty Index}

The indirect effects of applying zeolite to both rearing water and/or artificial diets will surpass the reliable correction of the undesirable environmental conditions, the positive effects on the morphometrical index (growth performance and feed utilization) and Production index to better health index. The health index includes better immunity status, less content of toxins in fish body, less deformities and pretty appearance. In this regard, James [31] found that Mozambique tilapia, Oreochromis mossambicus exposed to high content of cadmium $(6 \mathrm{ppm})$ and treated with $4 \mathrm{~g}$ zeolite/litre illustrated a significant decrease of cadmium content in both water and fish flesh, an improvement in the total counts of red blood cells, platelets, and Hemoglobin, increase in RBC size, and decrease in white blood cells. Surely that, the improvement of the health index of farmed fishes with produces better pretty-looking fishes (Figure 3). It is not excluded that fish encountering stresses (eg. excess content of heavy metals or ammonia) accentuates more secretion of Melanin-concentrating hormone (MCH) and melanocyte-stimulating hormone (MSH), which is secreted from hypothalamus gland and have a representative role in the regulation of pigment migration in fish body [32]. $\mathrm{MCH}$ secretion is changeable, depending on many environmental factors. Furthermore, zeolite incorporated into fish feed or added to rearing water produced better fish quality in terms of higher content of dry matter and protein and lower content of moisture and toxins $[24,31]$.

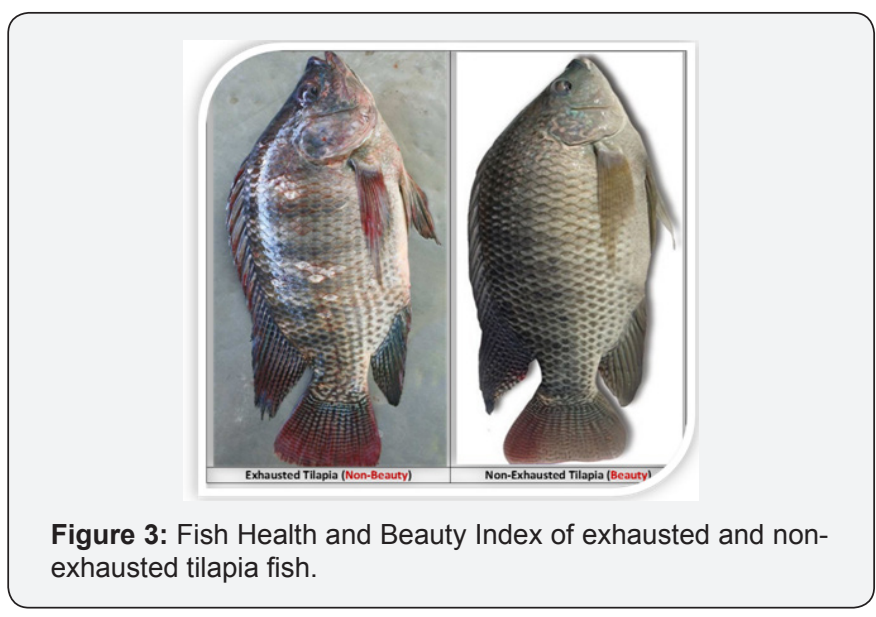

Specific Applications of Zeolites in Aquaculturerelated Activities

\section{Application of zeolites in sand filters}

The greater the surface area, the higher the material's sorption capacity [33]. Therefore, Sand filter supported with normal sands with particle sizes $0.5-2 \mathrm{~mm}$, has the ability to trap materials with particle sizes from 20-40 $\mu \mathrm{m}$. However, supporting sand filters with natural zeolites, will increase the efficiency of filters not only in terms of the amount of retained materials (organic matters, unwanted organisms such as algae, 
fungi, ocytes of fishes, other harmful organisms and even bacteria, etc.), but also the retained sizes up to $\leq 3 \mu \mathrm{m}$. The zeolite membranes with pore sizes between $0.05 \mu$ to $0.1 \mu \mathrm{m}$, were efficient at retaining bacteria and cysts through size exclusion mechanism and adsorption. Also, heavy metals (Fe,Mn) were reduced to nil, total dissolved solids ( $\mathrm{mg} / \mathrm{L}$ ) decreased up to $58 \%$ and between $82.24 \%$ and $100 \%$ bacterial population could be removed by the ceramic membranes depending on zeolite media [16]. One or more of the retained bacteria are pathogenic ones such as E. coli, Aeromonas veronii, etc. This means better water clarification. So, the required quantity of zeolite media to clarify the same volume of water, will be less in zeolite-supported filter compared with sand-supported filter. From an economical point of view, by adding zeolites to sand filter, the cost of operation and maintenance will decrease, as a result of increasing the required time period for backwash processes [16].

\section{Application of zeolites in biological filters}

Granular zeolites are recently being used inbiological filters as a substrate (media). There are many factors affecting the efficiency of biological filter. The most important one is total surface area (TSA) which is the residence place for nitrifying bacteria, such as (Nitrosomonas, Nitrobacter, Nitrococcus, etc.). Nitrifying bacteria is responsible for converting harmful by-products (such as ammonia and nitrite) to more safe and beneficial by-product (nitrate). The greater the surface area, the higher efficient nitrification process of biological filters [33]. Comparing the TSA of the common plastic media or sands used in biological filters with the TSA of zeolite of the same volume, we will discover that TSA for zeolite is hundred folds more than the previous medias [34]. That leads to double the efficiency of biological filters. The addition of zeolites as a media in biological filter indicated removal of up to 80 calcium, 89 magnesium, 99 iron, 56 arsenic, 54 fluorides, 96 turbidity, 37 nitrates and $41 \%$ total organic carbon [35]. Furthermore, the cost of ammonia removal (as $\mathrm{US} \$ / \mathrm{gmNH}_{3} / \mathrm{m}^{3}$ media/day) for zeolite filters will be much less. Also, in case the media of zeolite is saturated(100\%) with organic matter and ammonia after a long period of operation, this media can be reused as an organic fertilizer (Environmentally friend useful by-product). On the other hand, the plastic media will be a large burden on the environment to get rid of them. Plastics are most persistent pollutants left unchanged in the environment for centuries [34]. The biodegradation of synthetic plastics is a complex global phenomenon [35], and gaining great environmental interest. The complete biodegradation of plastic wastes needs hundred years and high costs for eco-friendly efficient treatment. Therefore, zeolite is one of the most powerful tools for biological fish filters.

\section{Application of zeolites in live fish transportation}

Zeolites can be used during transportation of live fish fry or broodstocks, especially if the time of transportation is more than 3 hours. Zeolite is very useful to avoid the accumulation of ammonia in fish holding facilities during fish transportation [17]. This issue is very important when we take into account the monetary and/or ecological value of transported fish. In some cases, the monetary value of fishes may exceed hundreds of thousands of US \$. Thus, tens of dollars may be the cheapest and safest way against the potential risk of lethal or sub-lethal content of ammonia.

\section{Recommended Dose}

\section{Feed addition}

The recommended dose in aquafeeds is practically dependent on the quality of feed ingredients used in feed industry and how much toxins they contain? In general, it is advised in case of using good quality raw materials, adding $1.5-2.5 \%$ zeolite to fish feed $[17,26,30,36,37]$.

\section{Water addition}

It is not easy to recommend a specific dose of zeolite, especially in case of applying zeolite in fish rearing water. The dose will actually depend on total fish biomass, protein content in feed, feed stability, and certainly the quality of water. In general, it is advised to add zeolite based on the expected and/ or actually measured quantity of nitrogenous byproducts. The average adsorption capacity of $25 \mathrm{mg} \mathrm{NH}^{4+} / \mathrm{g}$ zeolite could be relied upon to reduce the discharged wastes.

\section{Conclusion}

Sustainable aquaculture development aims to: achieve the maximum utilization of the avaible resources (water, feed, and varieties), produce good quantity of high quality seafood products, and get good profit margin, with less negative environmental impacts. Based on the previous discussed data, we can conclude that, all these goals can be accomplished partially or rather totally by practical and effective use of natural zeolites in fish farm management. This would guide us to maximum profitability of aquaculture industry.

\section{References}

1. FAO (2016) The State of World Fisheries and Aquaculture 2016. Contributing to food security and nutrition for all. Rome, Italy, p. 200.

2. GAFRD (2015) General authority for fish resources development, Report on fish production, Cairo, Egypt.

3. Petrus R, Warchoł J (2003) Ion exchange equilibria between clinoptilolite and aqueous solutions of $\mathrm{Na}^{+} / \mathrm{Cu}^{2+}, \mathrm{Na}^{+} / \mathrm{Cd}^{2+}$ and $\mathrm{Na}^{+} /$ $\mathrm{Pb}^{2+}$. Microporous and Mesoporous Materials 61: 137-146.

4. Benhammou A, Yaacoubi A, Nibou L, Tanouti B (2005) Adsorption of metal ions onto Moroccan stevensite: kinetic and isotherm studies. J Colloid Interface Sci 282(2): 320-326.

5. Guisnet M, Ribeiro FR (2011) Deactivation and regeneration of zeolite catalysts. World Scientifc, Catalytic Science Series. Imperial College Press, London, England, 9: 360.

6. Mikkers Y (2009) Regeneration of zeolites used for ammonium removal from anaerobic groundwater. Delft University of Technology, Delft, Netherlands.

7. Nieves M, Voltolina D, Medina A, Piña P, Ruiz JL (2002) Zeolites and diatom growth. Aquac Res 33: 75-79.

8. Boyd CE (1995) Bottom soils, sediment, and pond aquaculture. Chapman and Hall, New York, USA. 
9. Emadi H, Nezhad JE, Pourbagher H (2001) In vitro Comparison of Zeolite (Clinoptilolite) and Activated Carbon as Ammonia Absorbants in Fish Culture. Naga The ICLARM Quarterly 24 (1-2): 1-3.

10. Aly HA, Abdel-Rahim MM, Lotfy AM, Abdelaty BS, Sallam GR (2016) The Applicability of Activated Carbon, Natural Zeolites, and Probiotics (EM®) and Its Effects on Ammonia Removal Effciency and Fry Performance of European Seabass Dicentrarchus labrax. J Aquac Res Development 7: 459 .

11. Demir A, Gunay A, Debik E (2002) Ammonium removal from aqueous solution by ion-exchange using packed bed natural zeolite. Water SA 28(3): 329-336.

12. Malovanyy A, Sakalova H, Yatchyshyn Y, Plaza E, Malovanyy M (2013) Concentration of ammonium from municipal wastewater using ion exchange process. Desalination 329: 93-102.

13. Öz M, Şahin D, Aral O (2016) The Effect of Natural Zeolite Clinoptilolite on Aquarium Water Conditions. Hacettepe J Biol Chem 44(2): 205208.

14. Gholikandi GB, Baneshi MM, Dehghanifard E, Salehi S, Yari AR (2012) Natural Zeolites Application as Sustainable Adsorbent for Heavy Metals Removal from Drinking Water. Iranian Journal of Toxicology 3(3): 302-310.

15. James R (2000) Effect of zeolite on reduction of cadmium level in water and improvement of haematological parameters in Oreochromis mossambicus (Peters). Indian J Fish 47(1): 29-35.

16. Moralı N (2006) Investigation of Zinc and Lead Removal from Aqueous Solutions using Clinoptilolite. Ms c thesis, School of Natural and Applied Sciences of Middle East Technical University, p. 93.

17. Gopalan R, Venkappayya D, Nagarajan S (2013) Textbook of Engineering Chemistry. In: GopalanR, Venkappayya D, Nagarajan S (Eds.), Vikas Publishing House ( $4^{\text {th }}$ edn), pp. 608.

18. Ajenifuja E, Akinwunmi O0, Bakare MK Ajao JA, Adeniyi IF, et al. (2012) Remediation of Polluted Water Using Natural Zeolitic Aluminosilicates/ Lateritic Clay Ceramic Matrix Membrane. ISRN Ceramics 2012(2012): 11.

19. O Brine TMWM, Snellgrove DL (2012) Effects of natural zeolite (Clinoptilite) levels in goldfish diets on growth, water quality, and digestability of the Common Goldfish (Carassius auratus). AQUA 2012.

20. Chien YH (1992) Water quality requirements and man-agement for marine shrimp culture. In: Wayban J (Ed.), Proceedings of the Special Session on Shrimp Farming. Aquaculture. World Aquaculture Society, Baton Rouge, USA, pp. 144-146.

21. Jackson DD, Edward W, Bartow E (1916) Water Softening by Filtration through Artificial Zeolite. Journal (American Water Works Association) 3(2): 423-433.

22. Odilia G, Idania S, Oramas A (2006) Natural zeolite to reduce the water hardness. Technical note. Cuban Journal of Agricultural Science 40(2): $179-180$

23. Ortatatli M, Oguz H, Hatipojlu F, Karaman M (2005) Evaluation of pathological changes in broilers during chronic aflatoxin (50 and 100ppb) and clinoptilolite exposure. Res Vet Sci 78(1): 61-68.
24. Haile T, Nakhla G (2010) The inhibitory effect of antimicrobial zeolite on the biofilm of Acidithiobacillus thiooxidan. Biodegradation 21(1): 123-134.

25. Obradovic S, Adamovic M, Vukasinovic M, Jovanovic R, Levic J (2006) The application effects of natural zeolite in feed and water on production results of Oncorhynchus Mykiss (Walbaum). Roum Biotechnol Lett 11 (6): 3005-3013.

26. Eya JC, Parsons A, Haile I, Jagidi P (2008) Effects of Dietary Zeolites (Bentonite and Mordenite) on the Performance Juvenile Rainbow trout Onchorhynchus myskis. Australian Journal of Basic and Applied Sciences 2(4): 961-967.

27. El-Gendy MO, Gouda AH, Shehab El-DMT (2015) Effect of Zeolite on Feeding Rates and Growth Performance for Nile Tilapia (Oreochromis niloticus). International Journal of Scientific Research in Agricultural Sciences 2: 018-024.

28. Kanyılmaz M, Tekelioglu N, Sevgili H, Uysal R, Aksoy A (2015) Effects of dietary zeolite (clinoptilolite) levels on growth performance, feed utilization and waste excretions by gilthead sea bream juveniles (Sparus aurata). Animal Feed Science and Technology 200: 66-75.

29. Yildirim Ö, Türker A, Senel B (2009) Effects of natural zeolite (clinoptilolite) levels in fish diet on water quality, growth performance and nutrient utilization of Tilapia (Tilapia zillii) fry. Fresenis Environ Bulletin 18(9): 1567-1571.

30. Khodanazary A, Boldaji F, Tatar A, Dastar B (2013) Effects of Dietary Zeolite and Perlite Supplementations on Growth and Nutrient Utilization Performance, and Some Serum Variables in Common Carp, Cyprinus carpio). Turkish Journal of Fisheries and Aquatic Sciences 13: 495-501.

31. Barouei J, Yazdi GF, Dovom MRE, BalssiniMS, Yavarmanesh M (2014) Inclusion of Dietary Zeolite Reduces Aflatoxin $\mathrm{B}_{1}$ Levels in Household Bread Waste Used as Cattle Feed. Current Nutrition \& Food Science 10(2): 107-111.

32. Ergün S, Tekesoglu H, Yigit M (2008) Effects of dietary natural zeolite levels on ammonia excretion rates in young rainbow trout (Oncorhynchus mykiss). Fresen Environ Bull 17(2): 245-248.

33. Takahashi A, Mizusawa K, Amano M (2014) Multifunctional Roles of Melanocyte-Stimulating Hormone and Melanin-Concentrating Hormone in Fish: Evolution from Classical Body Color Change. AquaBio Science Monographs 7(1): 1-46.

34. Ray F, Onuma C, Yunfei X, Serge K (2007) Surface characterisation of selected sorbent materials for common hydrocarbon fuels. Surface Science 601(9): 2066-2076.

35. Mahlangu TO, Mpenyana-Monyatsi L, Momba MNB, Mamba BB (2011) A simplified cost-effective biosand filter (BSFZ) for removal of chemical contaminants from water. Journal of Chemical Engineering and Materials Science 2(10): 156-167.

36. Muthukumar A, Veerappapillai S (2015) Biodegradation of Plastics - A Brief Review. Int J Pharm Sci Rev Res 31(2): 204-209.

37. Sivan A (2011) New perspectives in plastic biodegradation. Current Opinion in Biotechnology. Curr Opin Biotechnol 22(3): 422-426. 
Your next submission with Juniper Publishers will reach you the below assets

- Quality Editorial service

- Swift Peer Review

- Reprints availability

- E-prints Service

- Manuscript Podcast for convenient understanding

- Global attainment for your research

- Manuscript accessibility in different formats ( Pdf, E-pub, Full Text, Audio)

- Unceasing customer service

Track the below URL for one-step submission https://juniperpublishers.com/online-submission.php 